\title{
Merre tovább, magyar információs politika?
}

Így hivatkozzon erre a cikkre:

Juhász Lilla. , Merre tovább, magyar információs politika?”. Információs Társadalom VII, 1. szám (2007): 121-123.

A folyóiratban közölt müvek

a Creative Commons Nevezd meg! - Ne add el! - Így add tovább! 4.0

Nemzetközi Licenc feltételeinek megfelelően használhatók. 
Juhász Lilla

\section{Merre tovább, \\ magyar információs politika?}

Az ITTK Szakmai Klubja 2002 júniusában látta elôször vendégül az (akkor felálló) Informatikai és Hírközlési Minisztérium vezetôit, akik a terveikról beszéltek. A számvetésre ismét a Szakmai Klub biztosított fórumot: az IHM munkájáról 2006 márciusában a tervezett és a megvalósult programok alapján vont mérleget a tárcát vezető Kovács Kálmán. A 2006. évi választásokat követố változások okairól ismét az ITTK Szakmai Klub rendezvényén, október 25-én adott számot az információs politika felelôs vezetôje. A meghívott vendég, Kóka János gazdasági és közlekedési miniszter a miértekról, az információs társadalom felépítésére irányuló programról és az IHM megszünéséból fakadó szerkezetváltozásról beszélt, kitérve az információs társadalom néhány sarkalatos kérdésére és az állami szerepvállalás lehetôségeire.

2004-tôl új korszak kezdődött az információs társadalom hazai kiépítésében: lezárult az infrastrukturális alapok megteremtésének időszaka. A miniszter szerint a vizionálás ideje lejárt, rövid- és középtávú célok meghatározására van szükség, amelyek az informatikai szakma együttmúködésének eredményeként egy Fehér Könyvben fognak megjelenni. A modern szolgáltató állam kiépítéséért felelős kormány elsősorban a szabályozási, fejlesztési és gazdaságpolitikai környezet kialakítását, valamint a verseny biztosítását tekinti feladatának. Az állami szerepvállalás háttérbe szorításában hisz, az információs társadalom vertikális képviselete helyett pedig a fejlesztési programok horizontális koordinálását túzi ki célul.

\section{Az Informatikai és Hírközlési Minisztérium megszüntetésének okai:}

Kóka János szerint négy évvel ezelôtt indokolt volt az IHM létrehozása, hiszen lefektette a stabil alapokat: egy digitálisan alulfejlett országban építette ki a szükséges infrastruktúrát. Tevékenysége az ország fejletlenségéból fakadóan mindenre kiterjedt. A kormányzati átalakítás (az IHM-nak a Gazdasági és Közlekedési Minisztériumba történt beolvasztása) legnagyobb érdemének a miniszter azt tekinti, hogy egyértelmú felelôsségi rendszer kialakítását hozta magával, „profiltisztítás” történt, és az alapok lerakása után végre az információs társadalom építése és az elektronikus gazdaság fejlesztése kerülhet a középpontba. A miniszter nemcsak a korábbi intézményrendszert, de a korábbi információs politikát is elutasítja: teljesen szakítani kíván azzal az informatikai politikával, ami az informatikai eszközökkel való ellátottság növelését tûzte ki célul (idetartozik például a Sulinet Expressz program és az eMagyarország hálózat is), de a hazai tapasztalatok alapján olyan részletes és kívánságlista jellegú kormányzati stratégia kialakítását sem tekinti üdvösnek, mint a Magyar Információs Társadalom Stratégia (MITS). 
A Gazdasági és Közlekedési Minisztérium mint az informatikáért és az információs politikáért felelốs tárca feladatait a miniszter a következókben látja:

1. A minisztérium feladatának tekinti a szabályozási, a fejlesztés- és gazdaságpolitikai környezet kialakítását, de elutasítja, hogy feleloosséget kellene vállalnia az információs társadalom kiépítéséért, a tárca feladata az információs társadalom kiépítésének koordinálása, indukálása. A tárca hatékonyságának mérésére az információs társadalom indikátorai között a darabszámokra koncentráló kimeneti indikátorok helyett az életminőség változását mérô hatásindikátorok megjelenítését sürgeti. Kiemelten fontosnak tartja az információs írástudás fejlődésének kérdéseit.

2. A tárca vezetôje szerint a minisztériumnak a szakmával szorosan együttmúködve azon kell munkálkodnia, hogy az államigazgatás egészében az információs társadalom kiépítéséhez szükséges feladatok kerüljenek elótérbe. Az informatikai szakma képviselőinek is szemléletváltáson kell átesniük, mert az ÚMFT tervezésekor nem az foglalkoztatta óket, hogyan lehet valamennyi programot - a gazdaságfejlesztéstól az infrastruktúra fejlesztéséig - a modernizáció, az információs írástudás üzeneteivel átitatni, hanem sokkal inkább az, hogy hányszor fordul elő az „információs társadalom” kifejezés a fejlesztési tervben.

3. Az informatikai fejlesztési igények felmérését, valamint a teljesítésükhöz szükséges eszközök biztosítását tekinti kulcsfontosságú feladatnak. Ezekrôl az igényekról világosan áttekinthető listát kíván készíttetni, olyan feladatsor meghatározásával, amit négy év alatt végre lehet és végre is kell hajtani.

4. A minisztérium rendelkezésére álló eszközöket az alábbiakban határozza meg: szabályozói tevékenység (jogszabályok megalkotása, illetve megváltoztatása), uniós fejlesztési források (a gazdaság fejlesztésére szánható források között a visszatérítendő, illetve vissza nem térítendő támogatási alapok szétválasztásával), továbbá - az államreform keretében - az informatika, valamint többek között a humán erôforrások és az infrastrukturális feltételek fejlesztésére fordítható hazai források, ösztönző eszközök, valamint a közszolgáltatások informatizálása (a tartalom és a funkció terén egyaránt).

5. Az állami szerepvállalás háttérbe szorításában hisz, az állami projekteket jóval kevésbé tartja hatékonynak, mint a gazdasági szereplók tevékenységét: a legfejlettebb technológiák alkalmazására a kormányzat csak késésekkel képes. Stratégia helyett egy ún. „Fehér könyvet” javasol, ami a kormányzati beavatkozások kereteit vázolja, és tartalmazza a piaci szereplókkel és az informatikai szakmával közösen meghatározott, négy év alatt végrehajtandó feladatokat, a célokat és az elérésükhöz szükséges eszközöket.

6. Költségvetési fejlesztési források biztosítása helyett a finanszírozási rendszerek átvizsgálását javasolja, és állami beavatkozást szorgalmaz ott, ahol az informatika mint hívószó nem szerepel. A miniszter az információs társadalom fejlesztésének egyik valós eszközét az elektronikus szolgáltatások (például az autópálya-matricák) fejlesztésében látja. 
7. A gazdaságpolitika legfóbb célkitûzésévé kívánja tenni a gazdasági környezet fejlesztését, a vállalkozások elốtt álló adminisztratív korlátok lebontásával.

Összegezve: a GKM az információs társadalom vertikális képviselete helyett a fejlesztési programok horizontális koordinálását tü:i ki célul. Központi programmenedzsment helyett a keresleti oldal helyi szereplói és a piaci szolgáltatók közötti együttmúködést kívánja ösztönözni. Ebból a struktúrából pedig egyenesen következik, hogy elutasítja a felïlröl irányitott fejlesstési programok gondolatát. 